\title{
A SIMPLE SAFE METHOD FOR CONTINUOUS INFUSION EPIDURAL ANALGESIA IN OBSTETRICS
}

\author{
A.O. Davies and I.W. Fettes
}

\begin{abstract}
Continuous infusion epidural anaesthesia may reduce the risks of hypotension, high spinal block and intravenous injection associated with repeated bolus injections. However, controlling the rate of a simple infusion is difficult and infusion pumps are expensive and bulky. We describe a method for continuous infusion epidural anesthesia using a $6 \mathrm{ml} / \mathrm{hr}$ capillary infusion device (Intraflo CFS-06F Sorenson Research Co., Salt Lake City, Utah) and bupivicaine 0.25 per cent. In a study of 50 patients, 35 ( 70 per cent) had adequate pain relief with the infusion alone for a mean time until delivery of 5 hours (range 2 to 13 hours). A further 11 patients (22 per cent) required only one top-up for the second stage of labour after a mean pain-free time of 5.4 hours (range 1.5 to 9.7 hours). There were no maternal or foetal complications related to the technique of continuous infusion used. No block went higher than the ninth thoracic dermatome at any time.
\end{abstract}

Key Words: Anaesthesia, obstetrical; Anaesthesia Techniques, epidural, continuous infusion.

THE FIRST EPIDURAL ANAESTHETIC may have been administered by James Corning in $1885 .^{\prime}$ In the intervening 95 years, the practice of epidural anaesthesia has become widespread, especially in obstetrics.

For long term use, the common technique is repeated bolus injection through an epidural catheter. The bolus injections all carry some risks. Sudden increases in sympathetic block can summate with aorto-caval compression to produce maternal hypotension and foetal distress. Bolus injection of local anaesthetic intrathecally may produce "total spinal" anaesthesia with hypotension and apnoea leading to loss of consciousness. A large volume of drug injected into an epidural vein can cause systemic toxicity due to high blood levels manifested by convulsions, coma, or circulatory collapse.

Therefore slow continuous infusion of local anaesthetic through the epidural catheter following an initial bolus injection, as first described by Dawkins, ${ }^{2}$ is theoretically safer ${ }^{3}$ than intermittent injection and can provide more consistent pain relief.

However, using gravity drip alone may result in flow rates that vary with time and become too

A.O. Davies, M.D., F.R.C.P.(C), Staff Anaesthetist; I.W. Fettes, M.B., Ch.B., F.R.C.P.(C), Anaesthetistin-Chief; North Bay Civic and St. Joseph's General Hospitals.

From The Department of Anaesthesia, St. Joseph's General Hospital, 720 McLaren Street, North Bay, Ontario, Canada. fast or too slow. ${ }^{4}$ Patients have even attempted to adjust their own drips, leading to excessive block. 5 The use of a mechanical infusion pump $p^{4,6}$ solves some of these problems, but the pumps are expensive, bulky and may break down. The flow rate may also be increased inadvertently.

We felt that a capillary tube device (Intraflo, CFS-06F, Sorenson Research Co., Salt Lake City, Utah) designed to deliver a constant slow flow infusion of $5-7 \mathrm{ml} / \mathrm{hr}$ could be adopted for use in continuous infusion epidural anaesthesia, since we found that we were using about $12 \mathrm{ml}$ of bupivicaine 0.25 per cent injected every two hours. The technique requires inexpensive, readily available, disposible equipment and the chance of accidental overdose is negligible. A preliminary study confirmed that the Intraflo devices did deliver between 5 and $7 \mathrm{ml} / \mathrm{hr}$ of fluid when the pressure infusion bags were inflated to 300 torr.

We therefore designed a study to ascertain whether our technique was effective in practice, and institutional approval was obtained.

\section{Methods and Materials}

Informed consent was obtained from each of a series of 50 consecutive patients admitted to the delivery suite who wished to have an epidural anaesthetic and whose labour was likely to last more than three hours. The epidurals were commenced when cervical dilatation was 3 to $5 \mathrm{~cm}$.

After an intravenous infusion of at least $500 \mathrm{ml}$ 
of crystalloid solution, epidural anaesthesia was induced with the patient in the left lateral decubitus position, using a \#16 Touhy needle in the L3-4 interspace. A Portex epidural catheter was advanced 2 to $4 \mathrm{~cm}$ into the epidural space. After negative aspiration for cerebrospinal fluid or blood, a test dose of 2 to $3 \mathrm{ml}$ of bupivicaine 0.25 per cent was given and, if there were no untoward sequelae, $10 \mathrm{ml}$ of bupivicaine 0.25 per cent was injected. After securing the catheter to the skin, the patient was then turned onto her right side and the blood pressure was checked every 5 minutes for 20 minutes.

During this period $10 \mathrm{ml}$ of normal saline was removed from a $50 \mathrm{ml}$ polyvinylchloride (P.V.C.) intravenous solution bag and $40 \mathrm{ml}$ of bupivicaine 0.5 per cent was added, using sterile precautions, to give a total of $80 \mathrm{ml}$ of bupivicaine 0.25 per cent. This was run through a standard intravenous infusion set and the P.V.C. bag was then inserted next to the bladder of a pneumatic blood infusion pump which was inflated to 300 torr. An Intraflo device (CFS-06F, Sorenson Research Company, Salt Lake City, Utah) designed to deliver $5-7 \mathrm{ml} / \mathrm{hr}$ was attached to the intravenous infusion set. After filling the dead space of the Intraflo, the red rubber bypass valve was cut off to prevent any bypass of the capillary tube. The Intraflo device, which incorporates a micropore bacteriological filter, was then attached to the epidural catheter as illustrated in Figure 1.

To check that the Intraflo was functioning normally, the drip rate from the intravenous infusion set was observed to ensure that it was about $6 \mathrm{microdrops} / \mathrm{min}$ or $1 \mathrm{big}$ drop/min.

Twenty minutes after the injection, the upper level of analgesia on each side was determined. The patients were encouraged to spend approximately equal lengths of time on their right and left sides. Their blood pressures and levels of epidural block were assessed every thirty minutes. The pressure bag was kept inflated to 300 torr.

If there was any question of the location of the catheter, aspiration could be accomplished by attaching a syringe to the transducer port of the Intraflo. Similarly, additional local anaesthetic could be injected through the same site, if necessary.

On the day following delivery, the patients were reassessed to determine the subjective effectiveness of the epidural block. This was scored as complete if the patient felt no pain from the time of insertion of the epidural. The block was adequate if the patient felt some discomfort at delivery but did not need other analgesics for

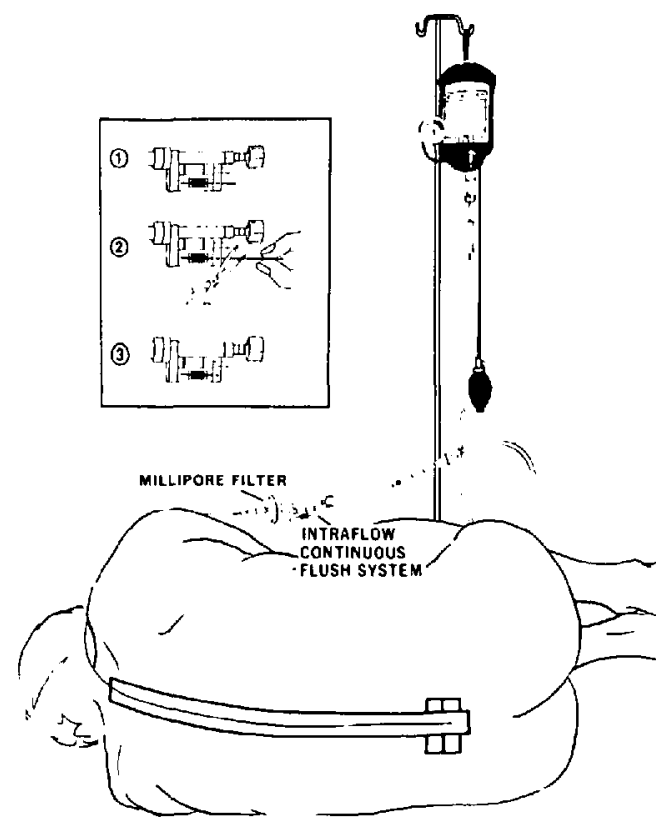

Figure I The setup of blood infusion pump. Intraflo, and epidural catheter. Note the red rubber bypass valve has been cut off the Intraflo to prevent excessive flow rate.

the episiotomy and the patient was satisfied with the block at the post-partum interview. The epidural was a failure if the patient was dissatisfied with the pain relief or needed other analgesics for labour and delivery.

Only two patients in this series went on to Caesarian Section and their perineal analgesia was assessed before injecting additional bupivicaine to allow intra-abdominal surgery.

\section{RESULTS}

The volume of local anaesthetic used for these patients was noted, and the flow rates produced by the Introflo in this clinical study were in the range expected (between 5 and $7 \mathrm{ml} / \mathrm{hr}$ ).

The quality and duration of analgesia with the continuous infusion is reported in Table I. This shows that thirty-five patients ( 70 per cent) needed only the initial injection and the continuous infusion for labour and delivery with a mean pain-free duration of 5 hours (range 2 to 13 hours). A further 11 patients ( 22 per cent) needed only one top-up for the second stage, so that 92 per cent of patients had adequate analgesia with, at most, one top-up.

The two failed epidural blocks in this series included one single nerve root block and one block which was initially successful but which 
TABLE I

Quality of ANalgesia with Continuous Infusion Epidural

\begin{tabular}{|c|c|c|c|c|c|c|}
\hline \multirow[b]{2}{*}{ Result } & \multirow[b]{2}{*}{ Number } & \multirow[b]{2}{*}{ Per cent } & \multicolumn{2}{|c|}{$\begin{array}{l}\text { Duration (hr) } \\
\text { before } \\
\text { Supplement } \\
\text { Necessary }\end{array}$} & \multicolumn{2}{|c|}{$\begin{array}{l}\text { Duration to } \\
\text { Delivery (hr) }\end{array}$} \\
\hline & & & Mean & Range & Mean & Range \\
\hline $\begin{array}{l}\text { 1. Complete Analgesia } \\
\text { - with infusion alone }\end{array}$ & 26 & 52 & 一 & - & 5.2 & $2-13$ \\
\hline $\begin{array}{l}\text { 2. Adequate Analgesia } \\
\text { - with infusion alone } \\
\text { - one top-up for delivery } \\
\text { - more than one top-up }\end{array}$ & $\begin{array}{r}9 \\
11 \\
2\end{array}$ & $\begin{array}{r}18 \\
22 \\
4\end{array}$ & $\begin{array}{c}- \\
5.4 \\
8\end{array}$ & $\begin{array}{c}\overline{5-9.7} \\
7-9\end{array}$ & $\begin{array}{l}4.7 \\
-\end{array}$ & $\begin{array}{c}2.5-7.5 \\
- \\
-\end{array}$ \\
\hline 3. Failure of Analgesia & 2 & 4 & - & - & - & - \\
\hline
\end{tabular}

could not be reinforced thereafter by any method.

Only four patients ( 8 per cent) needed additions to the original bolus to achieve complete analgesia. Twenty minutes after the initial dose, 17 per cent of the blocks were at T12 level, 43 per cent at T11 level, 32 per cent at T10, and 7 per cent at T9. During the continuous infusion, 24 per cent of blocks increased one or two segments, 45 per cent stayed the same and 30 per cent dropped one or two segments. No block was higher than T9 at any time

Only four patients ( 8 per cent) had transient blood pressure drops to less than 100 torr systolic with the initial injection. These were corrected with a fluid bolus. No patient required ephedrine. There were no episodes of hypotension noted during the continuous infusion.

One patient had an initial spinal tap before a successful epidural was established one level higher. One patient had a transient episode of "light-headedness" while rolling from one side to the other, and one patient developed a tension headache during labour. One patient had numbness in one leg for 12 hours after a difficult forceps delivery. None of these complications were related to the continuous infusion as such. There were no cases of neonatal depression or low Apgar score in this series.

\section{Discussion}

Continuous infusion epidural analgesia offers some advantages over bolus injection techniques. At our rate of infusion $(0.25 \mathrm{mg} / \mathrm{min}$ of bupivicaine), systemic toxicity is very unlikely if the catheter should enter an epidural vein. If the catheter perforated the dura, a slow increase in the level of block would be expected, since $10-15 \mathrm{mg}$ of isobaric bupivicaine have been used for spinal anaesthesia. ${ }^{7}$

If an obstetrical nurse is concerned about any feature of the infusion, he or she has only to turn it off and call the anaesthetist to assess the situation. The bypass valve of the Intraflo was cut off in this study as a safety precaution. However, even if this is pulled out on purpose, only 1 to $3 \mathrm{ml} / \mathrm{min}$ flow through the device, meaning that it would have to be held out for many minutes to achieve any drug overdose.

The workload of monitoring these patients with the continuous infusion is also spread out over time so that the care of the patients is easier for the hospital staff after the initial injection period. The continuous infusion technique also makes supervising the conduct of epidural anaesthesia less demanding for the anaesthetist in situations where the obsterical nursing staff are not permitted to give intermittent top-up injections.

Our particular technique was effective as 96 per cent of patients had adequate analgesia, 70 per cent of the patients needed only the initial bolus and the continuous infusion and 22 per cent needed only a single top-up for the second stage of labour.

Our results are comparable to those of Evans and Carrie, ${ }^{3}$ who used a continuous gravity drip of bupivicaine 0.25 per cent from a paediatric infusion set. They had an over-all success rate of 90 per cent with 33 per cent of the patients needing extra doses of bupivicaine. However, they used an average drip rate of $10 \mathrm{ml} / \mathrm{hr} \mathrm{com}$ pared to $6 \mathrm{ml} / \mathrm{hr}$ in our series. Matouskova, et al. ${ }^{8}$ using a continuous infusion pump, used a smaller initial dose and a rate of $5 \mathrm{ml} / \mathrm{hr}$. They had 
poorer results as 31 per cent needed top-ups in the first stage and only 30 per cent of patients had adequate analgesia in the second stage with the infusion alone.

No complications attributable to the equipment used were seen in our small series. Since the completion of this initial study, we have used the same method on 172 more patients and have yet to see any difficulties or complications referable to the technique.

We conclude that continous infusion epidural analgesia through a $6 \mathrm{ml} / \mathrm{hr}$ Intraflo capillary infusor with the bypass valve cut off, is an effective and safe method in our practice of obstetrical anaesthesia.

\section{ACKNOWLEDGEMENT}

The authors wish to thank Dr. J.D. Sinclair of the Department of Anesthesia and the members of the Department of Medical Art and Photography of St. Michael's Hospital, Toronto for producing the illustration.

\section{REFERENCES}

1. Little, D.M. Classical File. Survey of Anesthesiology 23: 271 (1979).

2. DAWKINS, M. Relief of postoperative pain by continuous epidural drip. Survey of Anesthesiology 1: 616-617 (1957).

3. Evans, K.R.L. \& Carrie, L.E.S. Continuous epidural infusion of bupivicaine in labour: a simple method. Anaesthesia 34: 310-315 (1979).

4. SCarborough, C.D. Continuous lumbar epidural anesthesia in the obstetrical patient: administration by the mechanical infusion pump. Southern Med. J. 65 : 1134-1135 (1972).

5. Bromage, P.R. Epidural Analgesia 1st ed. Philadelphia: WB Saunders Co. pp. 235-236 (1978).

6. Spoerel, W.E., Thomas, A. \& Gerula, G.R. Continuous epidural analgesia: Experience with mechanical injection devices. Canad. Anaesth. Soc. J. 17: 37-51 (1970).

7. Nolte, H. \& Stark, P. The dose effect ratio of isobaric bupivicaine in spinal analgesia. Reg. Anaes. 2: 1-4 (1979).

8. Matouskova, A., hanson, B., Elmén, H. Continuous mini-infusion of bupivicaine into the epidural space during labour - Part 11I: A clinical study of 225 patients. Acta Obstet. Gyn. Scand. (Suppl. 83): 43-52 (1979).

\section{RÉSUMÉ}

Une anesthésie péridurale par perfusion continue diminue les risques de complications du type observé avec les injections répétées dans le cathéter épidural, à savoir risques d'hypotension, de production de rachi-totale et d'injection dans une veine épidural. Toutefois le contrôle précis des perfusions est difficile sans l'aide d'équipement spécial et les pompes à infusion sont embarrassantes et coûteuses. Nous décrivons une méthode assurant une perfusion continue de $6 \mathrm{ml} /$ heure de solution analgésique au moyen d'un tube capillaire (Intraflo CFS-06 F Sorenson Research Co., Salt Lake City, Utah) et d'une solution de bupivacaine à 0.25 pour cent.

Dans une étude portant sur 50 parturientes on a observé un soulagement adéquat de la douleur chez 35 patientes ( 70 pour cent) avec l'emploi de cette seule méthode; la durée totale du travail et de l'accouchement sous analgésie a été de 2 à 13 heures (moyenne 6 heures). Chez 11 patientes (22 pour cent), il a été nécessaire de donner un supplément analgésique par volus pour la seconde phase du travail, ceci après une période d'analgésie allant de 1.5 à 9.7 heures (moyenne 5.4 heures). Aucune complication maternelle ou foetale liée à la méthode d’anesthésie n'a été relevée. On n'a jamais observé de bloc plus haut que le 9 ième dermatome. 